\title{
MDCT in the preoperative staging of gastric adenocarcinoma
}

\author{
O uso da TCMD no estadiamento pré-operatório do adenocarcinoma
}

Daniella Braz Parente ${ }^{1}$

Gastric cancer is the second cause of cancer-related mortality $^{(1-3)}$. The selection of the best therapeutic approach in cases of gastric adenocarcinoma is a complex task. Much has been discussed at international level in order to reach a consensus about the management of gastric adenocarcinomas in the clinical practice ${ }^{(4,5)}$. Multiple studies have also been developed to evaluate the accuracy of gastric adenocarcinoma staging by means of the different imaging modalities. The role of pelvic and abdominal multidetector-row CT in the investigation of the digestive system has been discussed in several studies recently published in the Brazilian literature ${ }^{(6-13)}$ and this has been the method of choice for preoperative staging of the disease ${ }^{(2,5,14,15)}$.

Pelvic and abdominal MDCT is a widely available imaging method capable of identifying local invasion and distant metastases. The staging with MDCT allows for less invasive treatments, such as endoscopic resection, in cases of early-detected tumors. On the other hand, patients with distant metastases might be spared extensive surgeries with curative intention ${ }^{(\mathbf{4 , 5 , 1 4})}$. It is important to emphasize that the obtention of better results is closely connect with the application of the correct technique. Thus, the stomach should be appropriately distended at the moment of the scanning. Studies describe gas distention and water distention techniques either effervescent granules taken orally, or ingestion of 750 to $1,000 \mathrm{~mL}$ of tap water immediately before the $\operatorname{scan}^{(16,17)}$.

The seventh issue if the TNM classification, published in 2010, incorporated some significant modifications. Because of their biological behavior, tumors located $5 \mathrm{~cm}$ proximal to the stomach should be staged as esophageal tumors. The T staging of tumors in the rest of the gastrointestinal tract is subdivided as follows: T2, defined as a tumor compromising the muscularis propria; T3, a tumor extending toward the subserous layer; and T4, a tumor invading the subserous layer or adjacent structures. Additionally, because of the abundant lymphatic chain in the gastric mucosa, leading to lymph node metastasis even with a tumor restricted to the lamina propria, the T1 category was subdivided into T1a (tumor restricted to the lamina propria or muscular layer of the mucosa); and T1b (submucosal invasion) ${ }^{(2,4)}$.

In the present issue of Radiologia Brasileira, Barros et al. ${ }^{\text {(18) }}$ evaluate the MDCT accuracy in the preoperative staging of patients

1. PhD, Radiologist at Hospital Universitário Clementino Fraga Filho - Universidade Federal do Rio de Janeiro (UFRJ) and Rede Labs D'Or (Fleury Group), Researcher at Instituto D'Or de Pesquisa e Ensino, Rio de Janeiro, RJ, Brazil. E-mail: daniella. parente@ gmail.com. with gastric adenocarcinoma in compliance with the TNM classification. The authors describe the cases of 50 patients with gastric cancer who underwent preoperative staging with 64-row multidetector computed tomography. A good accuracy was observed by the authors in the preoperative staging of gastric adenocarcinoma in relation to invasion depth and metastatic involvement. They highlight the specificity $\geq 95 \%$ for the diagnosis of early gastric cancer (T1) and $\geq 84 \%$ for detection of adjacent organs invasion (T4). In agreement with previous studies, the accuracy in the classification of lymph node involvement (category N) was low, demonstrating that such an evaluation still poses a challenge to radiologists. New studies utilizing different techniques such as radioactive markers, metabolic markers, molecular imaging, staining and magnetic resonance imaging are required to deepen the evaluation of $\mathrm{N}$ staging ${ }^{(\mathbf{1 9 - 2 2})}$.

Finally, MDCT plays an essential role in the preoperative staging of gastric adenocarcinoma, significantly influencing the selection of the best therapeutic approach. Gastric distention is indispensable to a correct tumor staging. The knowledge about the TNM staging system and a detailed description of findings including tumors, lymph nodes and metastasis is a radiologist's responsibility. Tumor $(\mathrm{T})$ and metastasis $(\mathrm{M})$ staging is accurately performed with MDCT. Further studies are required to improve lymph nodes (N) staging.

\section{REFERENCES}

1. Parkin DM, Bray F, Ferlay J, et al. Global cancer statistics, 2002. CA Cancer J Clin. 2005;55:74-108.

2. Edge SB, Compton CC. The American Joint Committee on Cancer: the 7th edition of the AJCC cancer staging manual and the future of TNM. Ann Surg Oncol. 2010;17:1471-4.

3. Torre LA, Bray F, Siegel RL, et al. Global cancer statistics, 2012. CA Cancer J Clin. 2015. [Epub ahead of print].

4. Coburn N, Seevaratnam R, Paszat L, et al. Optimal management of gastric cancer: results from an international RAND/UCLA expert panel. Ann Surg. 2014;259: $102-8$.

5. Dixon M, Cardoso R, Tinmouth J, et al. What studies are appropriate and necessary for staging gastric adenocarcinoma? Results of an international RAND/ UCLA expert panel. Gastric Cancer. 2014;17:377-82.

6. Kierszenbaum ML, von Atzingen AC, Tiferes DA, et al. Colonografia por tomografia computadorizada na visão do médico encaminhador: qual o seu valor segundo a visão de especialistas? Radiol Bras. 2014;47:135-40.

7. Maciel AC, Maciel LC. Colonografia por tomografia computadorizada: um método de rastreamento conhecido porém pouco utilizado. Radiol Bras. 2014;47(3):v-vi.

8. Terceiro MG, Faria IM, Alfenas R, et al. Hérnia de Amyand com apendicite perfurada. Radiol Bras. 2014;47(6):xi-xiii.

9. Santana Júnior PJ, Aurione ACV, Dangoni R, et al. Tumor neuroendócrino gástrico tipo III. Radiol Bras. 2014;47(4):xi-xii.

10. Monjardim RF, Costa DMC, Romano RFT, et al. Diagnóstico da esteatose hepá- 
tica pela tomografia computadorizada de abdome com meio de contraste intravenoso. Radiol Bras. 2013;46:134-8.

11. Salvadori PS, Costa DMC, Romano RFT, et al. Quando a fase de equilíbrio pode ser suprimida nos exames de tomografia computadorizada de abdome? Radiol Bras. 2013;46:65-70.

12. Costa DMC, Salvadori PS, Monjardim RF, et al. Quando a fase sem contraste intravenoso é desnecessária nos exames de tomografia computadorizada do abdome? Análise retrospectiva de 244 casos. Radiol Bras. 2013;46:197-202.

13. Teixeira ACV, Torres US, Westin CEG, et al. Tomografia computadorizada com multidetectores no diagnóstico pré-operatório das complicações intestinais causadas pela ingestão de corpos estranhos da dieta sem suspeita clínica: série de casos enfatizando o uso de técnicas de renderização volumétrica. Radiol Bras 2013;46:346-50.

14. Washington K. 7 th edition of the AJCC cancer staging manual: stomach. Ann Surg Oncol. 2010;17:3077-9.

15. Lee IJ, Lee JM, Kim SH, et al. Diagnostic performance of 64-channel multidetector $\mathrm{CT}$ in the evaluation of gastric cancer: differentiation of mucosal cancer (T1a) from submucosal involvement (T1b and T2). Radiology. 2010;255:805-14.

16. Shen $\mathrm{Y}$, Kang HK, Jeong $\mathrm{Y}$, et al. Evaluation of early gastric cancer at multidetector
CT with multiplanar reformation and virtual endoscopy. Radiographics. 2011; 31:189-99.

17. Pan Z, Pang L, Ding B, et al. Gastric cancer staging with dual energy spectral CT imaging. PLoS One. 2013;8:e53651.

18. Barros RHO, Penachim TJ, Martins DL, et al. Tomografia computadorizada de múltiplos detectores no estadiamento pré-operatório do adenocarcinoma gástrico. Radiol Bras. 2015;48:74-80.

19. Takeuchi H, Kitagawa Y. Sentinel lymph node biopsy in gastric cancer. Cancer J. 2015;21:21-4.

20. Qiao R, Liu C, Liu M, et al. Ultrasensitive in vivo detection of primary gastric tumor and lymphatic metastasis using upconversion nanoparticles. ACS Nano. 2015;9:2120-9.

21. Kim H, Lee SK, Kim YM, et al. Fluorescent iodized emulsion for pre- and intraop erative sentinel lymph node imaging: validation in a preclinical model. Radiology. 2014 Dec 3:141159. [Epub ahead of print].

22. Nakano T, Sakurai T, Maruyama S, et al. Indocyanine green fluorescence and three-dimensional imaging of right gastroepiploic artery in gastric tube cancer. World J Gastroenterol. 2015;21:369-72. 